\title{
The Secondary Equipment Market in the Positive Economic Development of the Agricultural Sector
}

\author{
${ }^{1}$ Airat A. Zamaidinov, ${ }^{2}$ Asiya K. Subaeva, ${ }^{3}$ Natalya R. Aleksandrova \\ ${ }^{1,2,3}$ Branch of Kazan (Volga Region) Federal University " in Chistopol, 422980, Chistopol, \\ Studencheskaya str, 15,432017, Ulyanovsk, bul'var Novyj Venec,1 \\ Email: subaeva.ak@mail.ru, Contact: (9375224482)
}

Received: 15th December 2017, Accepted: 20th December 2017, Published: 31st December 2017

\begin{abstract}
Technical support to and technological modernization of agriculture is an important direction in the development of agricultural production. At present, there is a tendency in agriculture to the obsolescence and break down of equipment. Partly, the acquisition of highperformance equipment and the introduction of resource-saving technologies, the use of combined soil cultivating and sowing units compensates for the deficit. At the same time, the level of supply with technical means of many agricultural enterprises does not allow for timely fulfillment of all technological operations in the set agrotechnical time limits [1]. As a consequence, the role of secondary technology in raising the level of agricultural machinery remains one of the important directions. The object of the study is Ulyanovsk Region. The study presents statistical data for 2011. The grouping of agricultural enterprises in Ulyanovsk region by their financial and economic indicators made it possible to divide all agricultural enterprises of the region into three groups and make recommendations for the development of technical potential. In this situation, the role of secondary machinery in increasing the level of technical provision of agriculture is becoming increasingly important.
\end{abstract}

Keywords: Agricultural Machinery, Level of Profitability, Security, Secondary Machinery, Repair Centers for Agricultural Machinery, Cluster, Foreign Agricultural Machinery.

\section{Introduction}

Agricultural engineering is one of the important factors in the development of the agro-industrial complex. The growth rate of the development of the agrarian sector depends on the level of technical availability. In conditions of financial instability of many agricultural enterprises, the secondary market of agricultural machinery is a convincing alternative to renewal of fixed production assets.
The largest part of the AIC of the regions of Russia feels an acute shortage in technology, so the use of the secondary market is the most acceptable. The main goal of this market is to provide agricultural producers with cheaper additional equipment, which becomes relevant against the background of low purchasing power [2].

The advantages of the market of second-hand agricultural machinery are low price in comparison with the new products; proven performance of machinery and equipment; the possibility of direct contact between the seller and the buyer, which shortens the delivery time of equipment; alternative methods of payment under contracts of sale; simplification of resale in a short time with more favorable conditions; braking of losses in the price in comparison with the new technology losing a high share in its price in the first years of operation. Disadvantages are: physical and moral wear and tear of machinery, non-provision of guarantees for operating units and for the whole range of machinery and equipment; and the risk in payments and supplies related to transportation and insurance [3].

\section{Methods}

Financial opportunities of agricultural enterprises do not leave a choice in the acquisition of new or second-hand equipment. Thus, more highlyprofitable enterprises, after a short period of operation, will begin to sell secondary equipment to less financially reliable households, which, in turn, sell their old worn machinery to the repair enterprises or to the least financially reliable counterparts [4].

Based on the financial possibilities of their level of profitability and on the need for additional means of mechanization of agricultural enterprises in Ulyanovsk region, we will divide them into three groups. 
Table 1 - Grouping of Agricultural Enterprises in Ulyanovsk Region in terms of Key Financial and Economic Indicators (by Districts) According to 2016 Data.

\begin{tabular}{|c|c|c|}
\hline \multicolumn{3}{|c|}{ Grouping of Districts based on the Results of Financial and Economic Activities of Agricultural Organizations } \\
\hline $\begin{array}{l}\text { Financial result from sales, thousand } \\
\text { rubles }\end{array}$ & $\begin{array}{l}\text { Number of } \\
\text { districts }\end{array}$ & Name of districts \\
\hline Group 1 (over 200,000) & 5 & $\begin{array}{l}\text { Melekessky, Novomalyklinsky, Cherdaklinsky, } \\
\text { Tsilninsky, Ulyanovsky }\end{array}$ \\
\hline Group $2(50,000-200,000)$ & 7 & $\begin{array}{l}\text { Veshkaimsky, Kuzovatovsky, Mainsky, Novospassky, } \\
\text { Radischevsky, Staromainsky, Sursky }\end{array}$ \\
\hline Group 3 (less than 50,000) & 8 & $\begin{array}{lcc}\text { Baryshsky, } & \text { Inzensky, Karsunsky, Nikolaevsky, } \\
\text { Pavlovsky, } & \text { Sengileevsky, Starokulatkinsky, } \\
\text { Terengulsky } & & \end{array}$ \\
\hline \multicolumn{3}{|c|}{ Grouping of Districts Based on the Level of Profitability of Economic Activity of Agricultural Organizations } \\
\hline Profitability level, \% & $\begin{array}{l}\text { Number of } \\
\text { districts }\end{array}$ & Name of districts \\
\hline Group 1 (over 30) & 4 & Karsunsky, Kuzovatovsky, Melekessky, Pavlovsky \\
\hline Group $2(15-30)$ & 10 & $\begin{array}{lrr}\text { Veshkaimsky, } & \text { Novomalyklinsky, } & \text { Novospassky, } \\
\text { Radishchevsky, } & \text { Starokulatkinsky, } & \text { Staromainsky, } \\
\text { Sengileevsky, Terengulsky, Ulyanovsky, } & \text { Tsilnitsky }\end{array}$ \\
\hline Group 3 (less than 15) & 6 & $\begin{array}{l}\text { Baryshsky, Inzensky, Mainsky, Nikolaevsky, Sursky, } \\
\text { Cherdaklinsky }\end{array}$ \\
\hline \multicolumn{3}{|c|}{$\begin{array}{l}\text { Grouping of Districts Based on the Level of Demand for the Main Types of Agricultural Machinery and the Need } \\
\text { for Repair Work }\end{array}$} \\
\hline Demand, un. & $\begin{array}{l}\text { Number of } \\
\text { districts }\end{array}$ & Name of districts \\
\hline Group 1 (over 200) & 4 & Melekessky, Ulyanovsky, Cherdaklinsky, Tsilninsky \\
\hline Group $2(100-200)$ & 7 & $\begin{array}{l}\text { Veshkaimsky, Mainsky, Novospassky, Radishchevsky, } \\
\text { Sengileevsky, Staromainsky, Sursky }\end{array}$ \\
\hline Group 3 (less than 100) & 9 & $\begin{array}{lrr}\text { Baryshsky, Inzensky, } & \text { Karsunsky, } & \text { Kuzovatovsky, } \\
\text { Novomalyklinsky, } & \text { Nikolaevsky, } & \text { Pavlovsky, } \\
\text { Starokulatkinsky, Terengulsky } & \end{array}$ \\
\hline
\end{tabular}

*According to the Consolidated Annual Reports of Agricultural Organizations in Ulyanovsk Region

Table 2 - Grouping of Agricultural Enterprises in Ulyanovsk Region in Terms of Main Indicators (by Districts)

\begin{tabular}{|c|c|c|}
\hline $\begin{array}{l}\text { Group } \\
\text { number }\end{array}$ & Name of districts & Group characteristics \\
\hline I & $\begin{array}{l}\text { Melekessky, Novomalyklinsky, } \\
\text { Tsilninsky, Ulyanovsky }\end{array}$ & $\begin{array}{l}\text { Agricultural enterprises often replacing their basic machinery } \\
\text { fleet: large, high-income, highly profitable enterprises that } \\
\text { have the opportunity to obtain bank loans. Enterprises that } \\
\text { operate complex machines for not more than } 5-7 \text { years. This } \\
\text { group will provide the secondary market with tractors, } \\
\text { combine harvesters, trucks, other complex machines that have } \\
\text { a large operational residual life. }\end{array}$ \\
\hline II & $\begin{array}{l}\text { Veshkaimsky, } \\
\text { Kuzovatovsky, } \\
\text { Novospassky, }\end{array}$ & $\begin{array}{l}\text { Less profitable agricultural enterprises operating their } \\
\text { machinery within the set tear and wear limits. The periodicity } \\
\text { of the acquisition of new complex machines is } 8 \text { to } 10 \text { years. } \\
\text { This group provides the secondary market with serviceable }\end{array}$ \\
\hline
\end{tabular}




\begin{tabular}{|c|c|c|}
\hline & $\begin{array}{ll}\text { Staromainsky, } & \text { Sursky, } \\
\text { Cherdaklinsky } & \end{array}$ & $\begin{array}{l}\text { complex machines, but at the same time requiring constant } \\
\text { and sufficiently high investment, and some of inoperative } \\
\text { machines that need repair. }\end{array}$ \\
\hline III & $\begin{array}{l}\text { Baryshsky, Inzensky, Nikolaevsky, } \\
\text { Pavlovsky, } \quad \text { Sengileevsky, } \\
\text { Starokulatkinsky, Terengulsky }\end{array}$ & $\begin{array}{l}\text { Low-profitable and loss-making agricultural enterprises. The } \\
\text { main share of equipment - second-hand complex machines } \\
\text { with more than } 8-10 \text { years of operation, second-hand } \\
\text { apparatuses, units and parts, including those requiring repair, } \\
\text { but which can be restored by own efforts. Enterprises of this } \\
\text { group supply machines that have served more than } 10 \text { to } 12 \\
\text { years, have a small residual life and serious technical flaws, } \\
\text { faulty machines not subject to repair. Among the enterprises } \\
\text { of this group the machine can several times go from hand to } \\
\text { hand as long as there are buyers. Further, the last owner can } \\
\text { sell a non-working equipment to a repair company or an } \\
\text { intermediary for parts or waste metal. }\end{array}$ \\
\hline
\end{tabular}

Recently, the number of profitable farms has increased and there is a tendency to decrease in the number of unprofitable farms, which can affect the growth of demand for new machines and accelerate their lifetime in the first buyer. These changes will affect the increase in the market of used equipment and the maintenance service market.

\section{Results}

Negmetzianov A.V. stated that "currently there is not only a secondary market for agricultural machinery with a service life of less than 10 years, but also a tendency to the restoration of decommissioned equipment and its pre-sale preparation, both in Russia and in other countries for supply to our market" [3].

After the transition to market relations, the planned delivery of new equipment and timely scheduled repairs have sunk into oblivion. The repair bases were closed, and the repair of machinery began to be carried out by own forces and capabilities. The development of the used equipment market began to be affected by financial and economic, organizational, technical and social factors [5,6].

With a new foreign equipment coming to the market, the used equipment market began to develop in a new direction. The secondary imported equipment had high technical indicators at a low price and even sometimes surpassed new Russian-made machinery. The following requirements have been established for the second-hand equipment: low price in comparison with the new one; the presence of moral and actual wear and tear; ensuring of its suitability for operation with possible motor resources and provision of guarantees as to new machinery $[3,7]$.

The development of the secondary equipment market is in close connection with the activity of the dealer companies providing technical preparation and sale of used equipment, the availability of trading platforms, the development of a repair and technical service base, the organization of an advertising campaign, etc.

\section{Discussion}

Development of this direction requires to conclude contracts for the purchase and sale of equipment, organize trading platforms, create a flexible price system and services, organize pre-sale preparation and after-sale maintenance of machinery. To obtain a positive result in this area, it is necessary to solve the organizational issues of technical maintenance of used equipment, information and consulting support for technical preparation, and sale of used equipment.

The development of the secondary machinery market in many regions is supported by the agricultural management authorities, other structures that support the development of agricultural production, as well as a significant share of state support [8].

Examples of such enterprises are regional distributors of agricultural machinery plants, which have good technical equipment, occupy the most advantageous geographical position; however, they unwillingly deal or do not carry out operations with used equipment, since their task will be to purchase, restore and sell used equipment. The market of repair and technical services has many small firms offering this type of services, however, the experience of operation and repair of many agricultural enterprises shows that the highest quality repair and maintenance of complex units of imported and foreign equipment with the guarantee is possible only in dealerships and specialized service centers. However, high cost of services leads to the abandonment of the services of these organizations and the repair of equipment by their own efforts.

At the same time, there is no close relationship between consumers of agricultural machinery and spare parts, machine building plants, information 
and consulting services and institutions of higher and secondary education.

\section{Summary}

We should point out the factors that stimulate the growth and development of the secondary market of agricultural machinery, which have their bases under indirect state influence (Fig. 1).

All the factors under consideration have a direct impact on the development of the secondary market of agricultural machinery.
The growing prices for agricultural products and agricultural machinery, with some support from the state, provide a synergistic effect for the development and renewal of the infrastructure of the agro-industrial complex and the market of secondhand agricultural machinery.

The growth and change in inflationary processes is exacerbated by the influx of prices for new agricultural machinery and, as a consequence, the growth of their level in the secondary market [9].

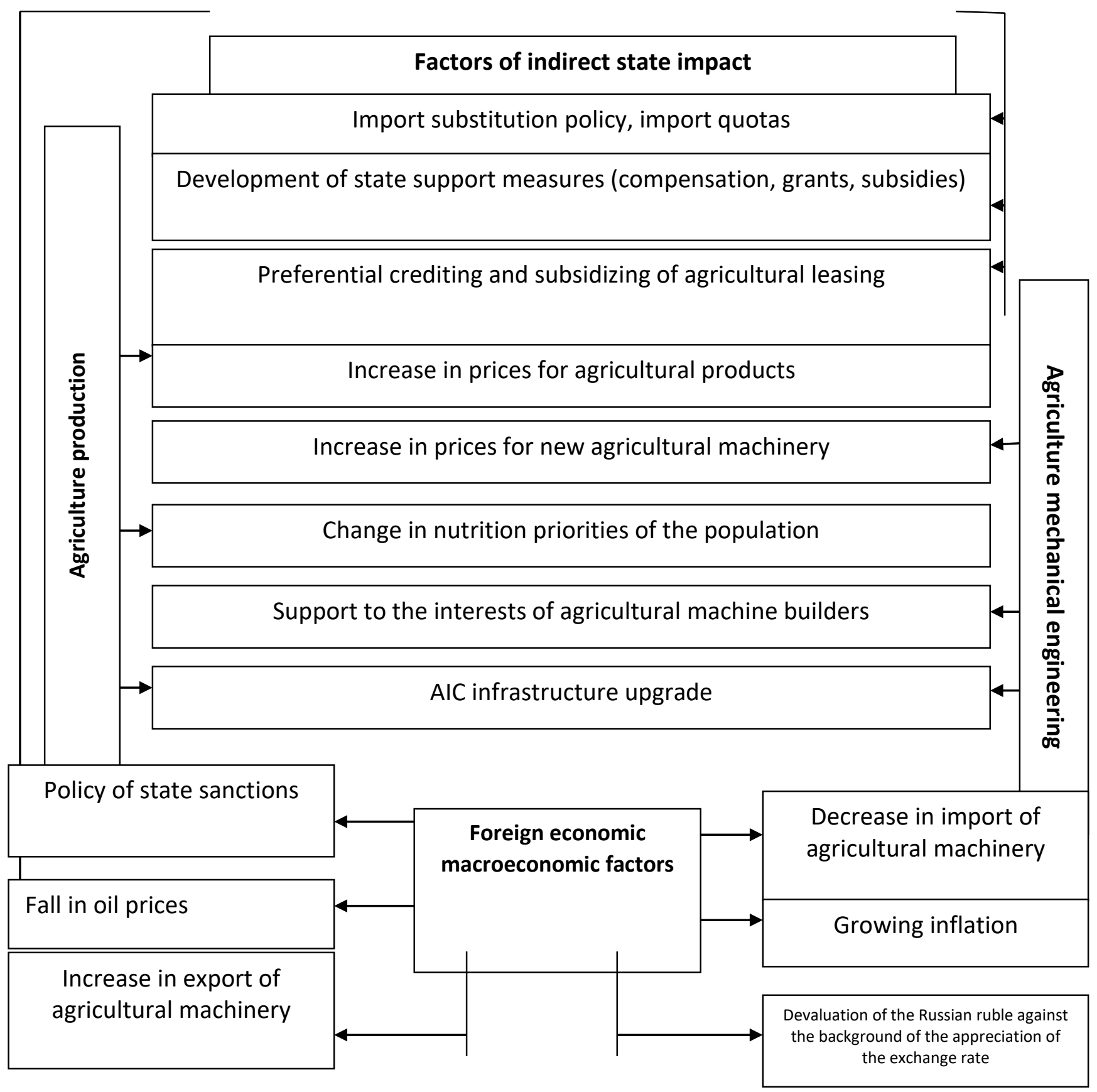

Figure 1 - Growth Factor of the Secondary Agricultural Machinery Market 
The fall in world oil prices and the depreciation of the Russian ruble led to higher prices in the secondary market of foreign agricultural machinery and their spare parts. To assess the prospects for the development of imports of agricultural machinery, it is necessary to take into account geopolitical problems and mutual economic sanctions between Russia and other countries that impede supply. All this leads to an increase in prices in the secondary market of imported equipment, which has a very negative effect on agricultural producers $[3,10]$.

\section{Conclusion}

Thus, the new and second-hand agricultural machinery market is subject to certain changes. It is mobile; the state comprehensively supports both the development of domestic agricultural machinery, and the financial and economic incentives for machinery buyers. The measures taken should strengthen the positions of Russian producers of agricultural products and machinery and raise their competitiveness.

\section{Acknowledgements}

The work is performed according to the Russian Government Program of Competitive Growth of Kazan Federal University.

\section{References}

[1] Polukhin A.A. Features of the use of the technical potential of Russian agriculture at the regional level / A.A. Polukhin // Education, Science and Production. - 2013. - No. 2 (3). - pp. 16 - 21.

[2] Alpatov A.B. Features of pricing in the market of domestic agricultural machinery in the framework of WTO and EEU agreements / A.V. Alpatov / Chief mechanic. - 2015. - No. 9. - pp. 56-68.

[3] Negmetzianov A.V. Optimization of the regional market of agricultural machinery: on the example of the Udmurt Republic: Thesis, PhD Economics: 08.00.05 / Negmetzianov Andrei Vladimirovich; [Place of defense: Udmurt State University]. Izhevsk, 2010. - p. 196.

[4] Subaeva A.K. The economic mechanism of technical support to agriculture (monograph) / A.K. Subaeva // Monograph - Kazan: Publishing house LLC "Publishing and printing company "Brig", 2016, p. 216.

[5] Alpatov A.V. Evaluation of the secondary market of agricultural machinery / A.V. Alpatov / Rural machinery operator. - 2016. - No.1. - pp. 4-7.

[6] Vodiannikov V.T., Sereda N.A. Reproduction of the technical potential of agriculture in the conditions of innovative development: monograph / V.T. Vodiannikov, N.A. Sereda. - Karavaevo: Kostroma State Agricultural Academy, 2014. - p. 228.

[7] Van Duijn J.J. Fluctuations in innovations over time. - Futures, 1981. Vol.13, - № 4. - P. 264-273. [8] Europe 2020. A strategy for smart, sustainable and inclusive growth. - European Commission, 2002, COM (2010) 2020 final.
[9] Subaeva A.K., Zamaidinov A.A. Classification of agroindustrial complex technical provision effectiveness indexes/ A.K. Subaeva, A.A. Zamaidinov A.A. // JOURNAL OF economics and Economic education research 2016; 4(17): 8-14 issn: 1533-3590

[10] Subaeva A.K., Zamaidinov A.A. Methods of agricultural machinery market regulation / A.K. Subaeva, A.A. Zamaidinov A.A. // International Business Management 2015; 9(7): 1780-1784. ISSN: 1993-5250. 